Jurnal Farmamedika Vol 4, No 2 Desember 2019

\title{
ANALISIS SIFAT FISIK, DAN KIMIA PADA TANAMAN PADI (Oriza sativa L.) YANG TERDAPAT DI DAERAH INDUSTRI MODERN CIKANDE
}

\author{
Diana Sylvia \\ Sekolah Tinggi Farmasi Muhammadiyah Tangerang \\ Korespondensi: didisylvia817@gmail.com
}

\begin{abstract}
ABSTRAK
Kawasan Industri Modern Cikande, merupakan daerah yang padat penduduknya, dan masih berada dalam tingkatan yang layak untuk aktivitas pertanian di kawasan urban, seperti pengolahan tanaman padi. Penduduk di sekitar kawasan industri ini memanfaatkan lahan yang ada untuk aktivitas pertanian, dimana pada lahan ini berdekatan dengan industri yang berpotensi mencemari hasil pangan. Sumber terbesar polusi di lahan ini adalah kontaminasi industri air yang digunakan untuk irigasi. Serta penggunaan pupuk anorganik juga dapat berpotensi terhadap adanya bahan pencemar yang terdapat pada tanaman padi. Tujuan penelitian ini adalah untuk mengetahui sifat fisika (warna, dan bau) dan sifat kimia ( $\mathrm{pH}$, dan kandungan logam) dari beras yang di tanam di sekitar kawasan industri. Pengambilan sampel beras diambil dengan metode random sampling dari tiga lokasi dekat dengan anak sungai yang digunakan sebagai tempat pembuangan limbah. Hasil penelitian menunjukkan bahwa warna dan bau dari beras adalah putih keruh dan berbau khas beras, sedangkan pengukuran $\mathrm{pH}$ dengan menggunakan $\mathrm{pH}$ meter didapatkan hasil nilai $\mathrm{pH}$ ratarata 6.5, dan pengukuran logam menggunakan metode Spektofotometri Serapan Atom (SSA) di Laboratorium Kimia Institut Pertanian Bogor (IPB) didapatkan nilai logam $\mathrm{Pb}$ sebesar < 0,04 ppm, logam Cd 0,045-1,676 ppm, logam Cr sebesar < 0,005 ppm, logam Hg sebesar <0,002 ppm, dan logam Fe 9,638-112,196 ppm. Hasil kadar tersebut terdapat batas maksimum yang diperbolehkan oleh FAO \& WHO, Permenkes RI No 492/menkes/per/IV/2010 dan Standar Nasional Indonesia 7387:2009 yaitu untuk logam Fe dan $\mathrm{Cd}$, sedangkan untuk logam $\mathrm{Pb}, \mathrm{Hg}$, dan $\mathrm{Cr}$ masih di bawah ambang batas yang ditentukan. Seluruh beras pada ketiga sampel menunjukkan adanya tingkat bahaya konsumsi apabila ditinjau dari nilai hazard quotient (HQ) karena lebih dari satu untuk kandungan logam $\mathrm{Fe}$ dan $\mathrm{Cd}$ dalam beras.
\end{abstract}

\section{Kata Kunci: Beras (Oriza sativa L.), pH, pencemaran logam erat, Spektofotometri Serapan Atom (SSA)}

\begin{abstract}
Cikande Modern Industrial Zone, is a densely populated area, and is still at a decent level for agricultural activities in urban areas, such as rice processing. Residents around the industrial area use the existing land for agricultural activities, where the land is adjacent to industries that have the potential to pollute food products. The biggest source of pollution on this land is industrial water contamination used for irrigation. And the use of inorganic fertilizers can also have the potential for the presence of pollutants found in rice plants. The purpose of this study was to determine the physical properties (color, and odor) and chemical properties $(\mathrm{pH}$, and metal content) of rice planted in the vicinity of the industrial area. Rice sampling was taken by random sampling from three locations close to a tributary used as a waste disposal site. The results showed that the color and odor of rice were turbid white and typical smelling of rice, while the $\mathrm{pH}$ measurement using a $\mathrm{pH}$ meter obtained an average $\mathrm{pH}$ value of 6.5 , and metal measurements using the Atomic Absorption Spectrophotometry (SSA) method at the Chemical Laboratory of the Bogor Agricultural University (IPB) obtained the value of $\mathrm{Pb}$ metal $<0.04 \mathrm{ppm}$, Cd metal 0.045-
\end{abstract}


1.676 ppm, Cr metal <0.005 ppm, Hg metal <0.002 ppm, and Fe metal 9.638-112.196 ppm. The results of these levels have a maximum limit allowed by FAO \& WHO, Republic of Indonesia Minister of Health Regulation No 492 / menkes / per / IV / 2010 and Indonesian National Standard 7387: 2009 for $\mathrm{Fe}$ and $\mathrm{Cd}$ metals, whereas for $\mathrm{Pb}, \mathrm{Hg}$ and $\mathrm{Cr}$ metals are still below specified threshold. All rice in the three samples showed a level of consumption hazard when viewed from the hazard quotient (HQ) value because more than one was for the $\mathrm{Fe}$ and $\mathrm{Cd}$ metal content in rice.

Keywords: Rice (Oriza sativa L.), pH, Heavy metal pollution, Atomic Absorption Spectrophotometry (AAS)

\section{PENDAHULUAN}

Padi merupakan tanaman pangan yang sangat penting di dunia, tanaman padi menjadi bahan pangan pokok bagi lebih dari setengah penduduk dunia. Padi sangat dibutuhkan sebagai pangan utama bagi lebih dari $90 \%$ penduduk Indonesia, karena memiliki kandungan karbohidrat tinggi dan sumber energi utama bagi penduduk indonesia terutama pada masyarakat pedesaan karena padi mampu memenuhi kebutuhan kalori 35-60\% bagi tubuh (1).

Mutu suatu beras sangat ditentukan oleh aktivitas budidaya tanaman padi yang dilakukan oleh petani dan kondisi wilayah dan lingkungan, dimana penggunaan pupuk anorganik dan pencemaran limbah industri berpotensi terhadap adanya bahan pencemar yang terdapat pada tanaman (akar, batang, daun dan buah) (2).

Peningkatan kegiatan perekonomian terutama sektor industri, senantiasa menimbulkan dampak positif dan dampak negatif. Dampak positif yaitu meningkatkan perekonomian, meningkatkan kesempatan kerja, meningkatkan taraf hidup masyarakat dan pertumbuhan ekonomi nasional. Dampak negatif yang dapat ditimbulkan, apabila penanganan limbah industri tersebut tidak tepat sehingga mengakibatkan pencemaran lingkungan (3).

Sektor industri yang semakin pesat memberikan dampak negatif terhadap sektor pertanian di wilayah Kawasan Industri Modern Cikande. Pencemaran logam berat pada aliran irigasi persawahan padi diduga disebabkan dari pembuangan limbah industri sekitar wilayah pertanian sehingga wilayah pertanian sekitarmenjadi tercemar dan mengakibatkan menurunnya kualitas tanah, air dan udara. Air irigasi yang digunakan dalam kegiatan pertanian tidak lepas dari unsur kimia, limbah hasil produksi masing-masing industri setempat yang banyak terdapat mengandung logam berat seperti Kadmium (Cd), Kromium $(\mathrm{Cr})$, Merkuri $(\mathrm{Hg})$, Timbal $(\mathrm{Pb})$, dan Besi (Fe) sehingga akan mengakibatkan adanya perubahan warna, bau dan derajat keasaman $(\mathrm{pH})$ pada tanaman padi tersebut. Menurut Kementerian Negara Kependudukan dan Lingkungan Hidup (1990), sifat toksisitas logam berat dapat dibagi ke dalam 3 kelompok, yaitu bersifat toksik tinggi yang terdiri dari unsur-unsur mercury $(\mathrm{Hg})$, cadmium $(\mathrm{Cd})$, timbal $(\mathrm{Pb})$, tembaga $(\mathrm{Cu})$ dan seng (Zn), bersifat toksik sedang terdiri dari unsur-unsur krom $(\mathrm{Cr})$, nikel (Ni)dan kobalt (Co). Adapun yang bersifat toksik rendah terdiri atas unsur mangan $(\mathrm{Mn})$ dan besi (Fe) (4).

Pencemaran logam berat pada padi tidak dapat diabaikan, karena dapat menyebabkan gangguan kesehatan manusia dalam jangka panjang akibat akumulasi pada organ, sehingga kaitan konsumsi pangan seperti padi dengan kesehatan sangat erat dan sulit untuk dipisahkan. Penyebab dari penyakit yang dihubungkan dengan bahan pangan sudah meningkatkan kesadaran konsumen mengenai mutu dan keamanan dari bahan pangan, sehingga kandungan konsentrasi logam berat dalam beras perlu diketahui dan untuk diperkirakan nilai toksiknya4).

Penentuan sifat fisika (warna dan bau) dilakukan secara organoleptik, untuk penentuan nilai $\mathrm{pH}$ dengan menggunakan pH meter, sedangkan kadar logam (PB, Cd, $\mathrm{Cr}, \mathrm{Hg}$ dan $\mathrm{Fe}$ ) dapat menggunakan metode 
Spektrofotometri Serapan Atom (SSA). Menurut Broekaert (2002) metode analisis dengan menggunakan Spektrofotometri Serapan Atom (Atomic Absorption Spectrophotometry, AAS) merupakan metode yang populer untuk analisa logam

\section{METODE PENELITIAN}

Penelitian dilaksanakan pada bulan September - November 2019 dan sampel dianalisis di Labolatorium Kimia dan Laboratorium terpadu, Institut Pertanian Bogor (IPB), Bogor, Jawa Barat.

Bahan yang digunakan adalah beras (Oriza sativa L.) yang ditanam di Daerah Industri Modern Cikande, $\mathrm{HNO}_{3}, \mathrm{H}_{2} \mathrm{SO}_{4}$, buffer 4 dan buffer 7 , aquadest, larutan baku standar $\mathrm{Pb}, \mathrm{Cd}, \mathrm{Cr}, \mathrm{Hg}$ dan $\mathrm{Fe}$.

Alat-alat yang digunakan dalam penelitian kali ini adalah timbangan analitik, labu ukur pyrex $500 \mathrm{ml}$, erlenmeyer pyrex $125 \mathrm{ml}$, ruang asam, hot plate, pipet mohr, labutakar pyrex $50 \mathrm{ml}$, labutakar pyrex $100 \mathrm{ml}, \mathrm{pH}$ meter, corongkaca, kertas saring, Spektofotometri Serapan Atom Shimadzu aa-7000.

Metode pengukuran logam berdasarkan metode deskriptif analisis kuantitatif, penelitian ini untuk mengetahui kandungan logam berat $\mathrm{Pb}, \mathrm{Cd}, \mathrm{Cr}, \mathrm{Hg}$ dan $\mathrm{Fe}$ yang terdapat pada beras (Oriza sativa L.) yang ditanam di Daerah Industri Modern Cikande. Berdasarkan FAO \& WHO dan Standar Nasional Indonesia 7387:2009.

\section{PROSEDUR PENELITIAN}

Pengambilan sampel beras diambil dengan metode random sampling dari tiga lokasi dekat dengan anak sungai yang digunakan sebagai tempat pembuangan limbah dengan dilakukan pengujian untuk melihat kualitas fisika dan kimia dari beras. Adapun parameter-parameter yang diuji dalam pengujian tersebut adalah:

\section{Sifat fisika}

\section{Warna dan bau}

Warna dan bau diamati langsung dengan bantuan organoleptik yaitu dilakukan oleh 3 orang responden untuk mencium bau dan melihat warna sampel beras, kemudian memberikan karena disamping relatif sederhana, metode ini juga selektif dan sangat sensitif. Oleh karena itu, SSA menjadi metode analisis yang sering digunakan untuk pengukuran sampel logam dengan kadar yang sangat kecil (5).

pendapat mengenai bau (berbau atau tidak) dan warna (berwarna atau tidak).

\section{Sifat kimia}

\section{a. Derajat keasaman (pH)}

Alat yang digunakan untuk mengukur $\mathrm{pH}$ adalah $\mathrm{pH}$ meter. Cara kerja untuk pengukuran $\mathrm{pH}$ air adalah sebagai berikut: menghidupkan alat dengan cara menekan tombol on/off, kemudian ditekan Cal hingga muncul insert pH pada layar monitor, selanjutnya elektroda dimasukkan ke larutan buffer $\mathrm{pH} 7$, setelah itu Cal ditekan sampai muncul nilai 7 pada layar monitor. Elektroda diangkat dan dibilas dengan menggunakan aquades. Langkah selanjutnya $\mathrm{Cal}$ ditekan sampai muncul insert buffer $\mathrm{pH} 4$ pada layar monitor, lalu elektroda $\mathrm{pH}$ dimasukkan ke dalam larutan buffer $\mathrm{pH} 4$ sampai muncul nilai $\mathrm{pH} 4$ pada layar monitor. Setelah selesai dikalibrasi, alat dapat digunakan untuk menetukan nilai $\mathrm{pH}$ pad sampel dengan cara sebagai berikut: (1) Memasukkan elektroda alat $\mathrm{pH}$ meter ke dalam sampel yang akan diukur (2) Menekan tombol read pada alat dan menunggu hingga nilai pada alat stabil. Angka yang tertera merupakan nilai $\mathrm{pH}$ pada sampel yang diukur.

\section{b. Kandungan logam berat}

Penyediaan larutan standar logam $\mathrm{Pb}, \mathrm{Cd}, \mathrm{Cu}, \mathrm{Hg}$ dan $\mathrm{Ni}$ dengan konsentrasi 100 ppm. Larutan standar untuk masing-masing logam diencerkan dengan berbagai variasi konsentrasi.

Preparasi sampel dilakukan dengan menggunakan metode destruksi basah yaitu dengan cara Ditimbang $5 \mathrm{~g}$ sampel beras yang 
51 | Diana Sylvia et al., (Analisis Sifat Fisik, dan Kimia Pada Tanaman...)

sudah di haluskan atau di tumbuk dimasukkan kedalam labu ukur kuran $500 \mathrm{~mL}$. Setelah dimasukan $\begin{array}{lllll}\text { tambahkan } 5 & \mathrm{~mL} & \mathrm{HNO}_{3} & \text { (p) }\end{array}$ didiamkan selama 1 jam pada suhu ruang di ruang asam. Setelah didiamkan diruang asam lalu panaskan diatas hot plate dengan temperatur yaitu $100^{\circ} \mathrm{C}-120^{\circ} \mathrm{C}$ selama 4-6 jam (dalam ruang asam). Setelah dipanaskan sampel dibiarkan semalam dalam keadaan tertutup, kemudian ditambahkan 0.4 $\mathrm{mL} \mathrm{H}_{2} \mathrm{SO}_{4}$ (p), lalu dipanaskan diatas hot plateselama \pm 1 jam sampai berwarna coklat. Pemanasan terus dilanjutkan sampai ada perubahan warna dari coklat menjadi kuning tua sampai kuning muda (biasanya \pm 1 jam). Setelah ada perubahan warna, pemanasan masih

\section{HASIL DAN PEMBAHASAN Hasil}

Hasil pengamatan mengenai gambaran analisis sifat fisika dan kimia pada tanaman dilanjutkan selama 10-15 menit. Pindahkan sampel, kemudian dinginkan dan tambahkan $2 \mathrm{~mL}$ aquades, setelah dingin panaskan kembali agar sampel $\operatorname{larut}( \pm 15$ menit) kemudian masukkan kedalam labu takar 100 mL.Apabila ada endapan disaring dengan glass wool atau kertas saring whatmen No. 42 .

Sampel yang telah dipreparasi selanjutnya dianalisis dengan Spektrofotometri Serapan Atom (SSA), prosedur kerja untuk pengoperasian analisis tersebut dengan memakai panjang gelombang yang sesuai untuk masingmasing logam berat $\mathrm{Pb} 283,3 \mathrm{~nm}$, logam $\mathrm{Cd}$ $228,8 \mathrm{~nm}$,logam Cr 357,9 nm nm, logam $\mathrm{Hg} 253,7 \mathrm{~nm}$ dan logam Fe 248,3 nm.

padi (Oriza sativa 1.) yang terdapat di daerah industri modern Cikandedapat dilihat pada tabel berikut:

Tabel 1. Analisis sifat fisika dan kimia pada tiga sampel beras

\begin{tabular}{|c|c|c|c|c|c|c|}
\hline No & $\begin{array}{l}\text { Variabel } \\
\text { yang } \\
\text { diamati }\end{array}$ & $\begin{array}{l}\text { Hasil } \\
\text { pengukuran } \\
\text { beras } 1\end{array}$ & $\begin{array}{l}\text { Hasil } \\
\text { pengukuran } \\
\text { beras } 2\end{array}$ & $\begin{array}{l}\text { Hasil } \\
\text { pengukuran } \\
\text { beras } 3\end{array}$ & Unit & $\begin{array}{l}\text { Batasan } \\
\text { maksimum }\end{array}$ \\
\hline 1 & Bau & $\begin{array}{l}\text { Bau khas } \\
\text { beras }\end{array}$ & $\begin{array}{l}\text { Bau khas } \\
\text { beras }\end{array}$ & $\begin{array}{l}\text { Bau khas } \\
\text { beras }\end{array}$ & - & \\
\hline 2 & Warna & Putih keruh & Putih keruh & Putih keruh & - & \\
\hline 3 & $\mathrm{pH}$ & 6,7 & 6,4 & 6,6 & - & $6,5-8,5$ \\
\hline \multirow[t]{2}{*}{4} & $\begin{array}{l}\text { Logam } \\
\mathrm{Pb}(1)\end{array}$ & $<0,04$ & $<0,04$ & $<0,04$ & ppm & $0,5 \mathrm{ppm}$ \\
\hline & $\begin{array}{l}\text { Logam } \\
\mathrm{Pb}(2)\end{array}$ & $<0,04$ & $<0,04$ & $<0,04$ & ppm & \\
\hline \multirow[t]{2}{*}{5} & $\begin{array}{l}\text { Logam } \\
\text { Cd (1) }\end{array}$ & 0,189 & 1,676 & 0,056 & ppm & $0,4 \mathrm{ppm}$ \\
\hline & $\begin{array}{l}\text { Logam } \\
\text { Cd (2) }\end{array}$ & 0,089 & 1,576 & 0,045 & ppm & \\
\hline \multirow[t]{2}{*}{6} & $\begin{array}{l}\text { Logam } \\
\mathrm{Cr}(1)\end{array}$ & $<0,005$ & $<0,005$ & $<0,005$ & ppm & $0,05 \mathrm{ppm}$ \\
\hline & $\begin{array}{l}\text { Logam } \\
\text { Cr (2) }\end{array}$ & $<0,005$ & $<0,005$ & $<0,005$ & ppm & \\
\hline \multirow[t]{2}{*}{7} & $\begin{array}{l}\text { Logam } \\
\mathrm{Hg}(1)\end{array}$ & $<0,002$ & $<0,002$ & $<0,002$ & ppm & 0,05 ppm \\
\hline & $\begin{array}{l}\text { Logam } \\
\text { Hg (2) }\end{array}$ & $<0,002$ & $<0,002$ & $<0,002$ & ppm & \\
\hline \multirow[t]{2}{*}{8} & $\begin{array}{l}\text { Logam } \\
\mathrm{Fe}(1)\end{array}$ & 25,031 & 9,807 & 112,196 & ppm & $0,3 \mathrm{ppm}$ \\
\hline & $\begin{array}{l}\text { Logam } \\
\mathrm{Fe}(2)\end{array}$ & 24,733 & 9,638 & 106,474 & ppm & \\
\hline
\end{tabular}

\section{Pembahasan}

\section{Warna dan bau}

Warna dan bau pada beras dapat disebabkan karena adanya bahan organik dan bahan anorganik yang terkandung dalam beras tersebut. Hasil pengamatan pada sampel beras 1,2 dan 3 memiliki warna tidak berbeda jauh, warna yang diamati berwarna putih keruh dan merupakan warna beras pada umumnya. Sedangkan bau yang diperoleh dari sampel beras 1, 2, dan 3 berbau khas beras pada umumnya. 


\section{Derajat keasaman pH}

Derajat keasaman $(\mathrm{pH})$ air yang lebih kecil dari 6,5 atau $\mathrm{pH}$ asam dapat meningkatkan korosifitas pada benda-benda logam, menimbulkan rasa tidak enak dan dapat menyebabkan beberapa bahan kimia menjadi racun yang mengganggu

\section{Logam berat}

Pada tabel 1 dapat diketahui bahwa kadar logam $\mathrm{Pb}, \mathrm{Cr}$, dan $\mathrm{Hg}$ pada sampel beras 1, 2 dan 3 masih dalam batas maksimum yang diperbolehkan oleh FAO \& WHO dan Standar Nasional Indonesia 7387:2009. Sedangkan untuk logam Cd pada beras 2 melebihi batas maksimum yang telah ditetapkan oleh Standar Nasional Indonesia 7387:2009 (8). Untuk logam Fe pada sampel beras 1 , 2, dan 3 melebihi batas maksimum yang telah ditetapkan oleh Standar Nasional Indonesia 7387:2009.

Logam $\mathrm{Pb}$ pada sampel beras 1, 2 dan 3 memiliki nilai $<0,04$ ppm. Dimana hasil analisis pada sampel beras 1, 2, dan 3 masih dibawah batas maksimum yang diperbolehkan oleh Standar Nasional Indonesia 7287:2009. Batas maksimum yang diizinkan adalah $0,5 \mathrm{ppm}$.

Logam Cr pada sampel beras 1, 2 dan 3 memiliki nilai $<0,005$ ppm. Dimana hasil analisis pada sampel beras 1, 2, dan 3 masih dibawah batas maksimum yang diperbolehkan oleh Standar Nasional Indonesia 7287:2009. Batas maksimum yang diizinkan adalah $0,05 \mathrm{ppm}$.

Logam $\mathrm{Hg}$ pada sampel beras 1 dan 3 memiliki nilai $<0,002 \mathrm{ppm}$. Dimana hasil analisis pada sampel beras 1, 2, dan 3 masih

\section{Potensi resiko logam berat terhadap kesehatan}

Batas yang ditoleransi untuk dikonsumsi yaitu $\mathrm{Pb} 0.025 \mathrm{mg} / \mathrm{kg} / \mathrm{hari}, \mathrm{Cd}$ $0.007 \mathrm{mg} / \mathrm{kg} / \mathrm{hari}$, Fe $0.8 \mathrm{mg} / \mathrm{kg} / \mathrm{hari}, \mathrm{Cr}$ $0.023, \mathrm{mg} / \mathrm{kg} / \mathrm{hari}$ (6). Bila nilai rerata logam berat $\mathrm{Cr}$ yang dikonsumsi bersama beras lebih besar dibandingkan batas yang masih ditoleransi, sehingga perlu treatment tertentu pada proses pasca panen agar aman dikonsumsi. Menurut IARC (7) logam Cd, $\mathrm{Cr}$, As, dan Ni termasuk kategori logam kesehatan. Pada tabel 1 diketahui bahwa hasil pengujian sampel beras 1 dan 3, masih memenuhi standar yang diizinkan oleh Standar Nasional Indonesia 7387:2009yaitu antara 6,5-8,5. Sedangan untuk sampel beras 2 memiliki nilai $\mathrm{pH} \quad 6,4$ tidak memenuhi standar yang diizinkan.

dibawah batas maksimum yang diperbolehkan oleh Standar Nasional Indonesia 7287:2009. Batas maksimum yang diizinkan adalah 0,05 ppm.

Logam Cd pada sampel beras 1 dan 3 memiliki nilai kadar masih di bawah $<0,4$ ppm. Sedangkan nilai kadar pada beras 2 dengan pengulangan pertama sebesar 1,676 ppm dan pengulangan kedua sebesar 1,576 ppm. Dimana hasil analisis pada sampel beras 1 dan 3 masih berada dibawah batas maksimum, sedangkan untuk beras 2 memiliki kadar nilai melebihi batas maksimum yang diperbolehkan oleh Standar Nasional Indonesia 7287:2009.Batas maksimum yang diizinkan adalah $0,3 \mathrm{ppm}$.

Logam Fe pada sampel beras 1 dengan kadar nilai pengulangan satu sebesar 25,031 ppm, dan pengulangan kedua sebesar 24,733 ppm. Pada beras 2 dengan kadar nilai pengulangan satu sebesar 9,807 ppm, dan pengulangan kedua sebesar 9,638 ppm. Pada beras 3 dengan kadar nilai pengulangan satu sebesar 112,196 ppm, dan pengulangan kedua sebesar 106,474 ppm. Dimana pada hasil analisis sampel beras 1, 2 dan 3 kadar Fe melebihi batas maksimum yang diperbolehkan oleh Standar Nasional Indonesia 7387:2009. Batas maksimum yang diizinkan adalah $0,3 \mathrm{ppm}$.

yang dapat memicu kanker. Asupan logam berat melalui beras merupakan mata rantai paparan logam berat yang penting, tetapi paparan melalui jalur lain tidak bisa diabaikan.

\section{KESIMPULAN}

Berdasarkan hasil penelitian Analisis sifat fisika dan kimia yang terdapat daerah Industri Modern Cikande, maka dapat disimpulkan bahwa:

1. Sifat fisika berdasarkan warna dan bau, 
53 | Diana Sylvia et al., (Analisis Sifat Fisik, dan Kimia Pada Tanaman...)

masih merupakan warna khas beras pada umumnya yaitu putih keruh. Sedangkan bau yang diperoleh dari sampel beras 1, 2, dan 3 berbau khas beras pada umumnya.

2. Sifat kimia pada $\mathrm{pH}$ sampel beras 1 dan 3 masih berada pada batasan nilai $\mathrm{pH}$ yaitu $6,5-8,5$, sedangkan nilai $\mathrm{pH}$ untuk sampel beras 2 dibawah 6,5. Untuk

3. 2 memiliki kadar nilai melebihi batas maksimum yang diperbolehkan oleh Standar Nasional Indonesia 7287:2009. Untuk nilai kadar Fe ketiga sampel

\section{DAFTAR PUSTAKA}

[1] Mulyaningsih, E. S., \& Indrayani, S. 2014. Keragaman Morfologi dan Genetik Padi Gogo Lokal Asal Banten. Jurnal Biologi Indonesia 10(1), 119-128.

[2] Fitrianah, L. 2016. Dampak Pencemaran Aktivitas Kendaraan Bermotor Terhadap Kandungan Timbal $(\mathrm{Pb})$ Dalam Tanaman Padi Dan Beras.

[3] Affandi, H., Hermanto, S., \& Etriya, F. 2015. Analisa Biomassa dan Kandungan Logam Berat Pada Beras Merah Hasil Pemupukan Kompos Sludge dari Pabrik Kertas dan Pulp. UIN Syarif Hidayatullah Jakarta: 202-209.

[4] Syahfitri, W., Damastuti E., \& Kurniawati, S. 2011. Penentuan Logam Berat $\mathrm{Cr}$, Co , Zn, dan $\mathrm{Hg}$ Pada Beras dan Kedelai dari Wilayah Kota Bandung. Prosiding Seminar Nasional Sains Dan Teknologi Nuklir, 213-219. kadar logam yang diujikan menggunakan alat SSA, didapatkan hasil untuk logam $\mathrm{Pb}, \mathrm{Cr}, \mathrm{Hg}$, pada ketiga sampel beras masih dibawah batas maksimum yang diperbolehkan oleh Standar Nasional Indonesia 7287:2009. Untuk nilai kadar Cd pada sampel beras.

beras melebihi batas maksimum yang diperbolehkan oleh Standar Nasional Indonesia 7387:2009.

[5] Oktrin Rustika Kumalawati. 2016. Analisis Kadar Logam Timbal $(\mathrm{Pb})$ Pada Bedak Tabur Dengan Variasi Zat Pengoksidasi Dan Metode Destruksi Basah Menggunakan Spektroskopi Serapan Atom (SSA).UIN Maulana Malik Ibrahim malang.

[6] US. EPA. Report on the 2011 U.S. Environmental Protection Agency (EPA) Decontamination Research and Development Conference. U.S. Environmental Protection Agency, Washington, DC, EPA/600/R/12/557, 2012.

[7] Fao, \& Who. 2011.Contamination In Foods. Codex Alimentarius Commision, 4-9. International Agency for Research on Cancer (IARC) / WHO. (2012). GLOBOCAN 2012: Estimated cancer incidence, mortality,and prevalence world wide in 2012.

[8] Standar Nasional Indonesia 7383. 2009. Batas Maksimum Cemaran Logam Berat Dalam Pangan.Badan Standardisasi Nasional. 